\title{
IMPROVING ECONOMIC POSITION OF VIET NAM IN ASEAN ECONOMIC COMMUNITY (AEC) FROM THE GLOBAL INTEGRATION PERSPECTIVES
}

\author{
To Thi Kim Hong \\ Ho Chi Minh City Open University
}

Email: hong.ttk@ou.edu.vn

\author{
Nguyen Anh Tuan \\ University of Economics and Law, HCMC National University \\ Email:tuanna@uel.edu.vn
}

\section{Tran Thi Kim Đao}

University of Economics and Law, HCMC National University

Email:aottk@uel.edu.vn

\section{Nguyen Minh Đuc}

Van Hien University

Email:ucnm@vhu.edu.vn

\begin{abstract}
After participating in ASEAN, and through various dialogue mechanisms, Vietnam now has become a more important and comprehensive economic member of the ASEAN Economic Community. This study focuses on analyzing the process of participating in the ASEAN Community and the roles and contributions of Vietnam in this organization to affirms Vietnam's position in the process of forming the AEC and demonstrates Vietnam's priorities for the integration process. The paper uses the primary and secondary data by using tools of desk research of different data in relativeness and by the quantitative method by using the Cobb-Doughlas function with a logarithmic form. The paper confirms the integration of Vietnam's economy into the ASEAN Economic Community (AEC) is an inevitable development after the achieved results of ASEAN's cooperation and economic connection. The AEC is an open regional economic integration model. The implementation of the AEC will bring in multi-dimensional impacts on member countries, and the extent of these impacts will depend on the level of regional and international economic integration, competitiveness, and effectiveness of policy reform in each country.
\end{abstract}

Keywords: economic integration, economic position, Vietnam, ASEAN economic community (AEC) 


\section{Introduction}

Establishing in 2015, the ASEAN Economic Community (hereinafter abbreviated as AEC) has been marked as a milestone, promote new and great cooperation, and show the deeper integration of ASEAN countries in the economic discipline. The AEC creates a unified market and production base which enables ASEAN countries to promote their competitive advantages and efficiently distribute resources in the region (Nguyen et al., 2008). In addition, that integration develops a more favorable business environment, eliminates barriers for businesses and investors inside/ outside of the AEC, and consequently, AEC will create much motivation for the development of ASEAN countries (Nguyen et. al., 2015). As an emerging economy, Vietnam owns many opportunities and takes advantage of and in AEC integration which is crucial for the development of Vietnam (Ha, 2013). More of that, after 26 years of joining the ASEAN, Vietnam has made many major contributions to turn ASEAN into a framework of peaceful cooperation and mutual development and has become an important and active economic member of the ASEAN Economic Community.

To date, Vietnam's economy has reached great milestones by deep integration with the international economy (Pham \& Vuong, 2009) through the annual GDP growth rate. As known, economic development depends much on international integration by its many benefits including the release of resources and the formation of a new economic development mindset, and the promotion of building standards in management, production structure, and business culture (Phan, 2007). That development results from the linking of economies of each country with the regional and international economies, the elimination of trade barriers, and the promotion of the free movement of goods, services, labor, and capital. Besides, regional economic integration brings the elimination of tariff and non-tariff barriers among members, establish a common foreign trade policy including agreements on trade restrictions with non-member countries, promote the free movement of goods, services as well as crossborder factors of production, unify monetary policy, and establish a common currency, etc. Besides, the position of the country is also considered through its competitive capability (Nguyen, 2020). This study focuses on analyzing the process of participating in the ASEAN Community and the roles and contributions of Vietnam in this organization to affirms Vietnam's position in the process of forming the AEC and demonstrates Vietnam's priorities for the integration process.

\section{Overview of Vietnam Economy Outlook}

As known, Vietnam is one of the dynamic emerging economies which is agreed to be in the progressing development aiming to economic modernization and proactively building up competitiveness, enhancing exports and encouraging service industries ( $\mathrm{PwC}, 2016)$. Indeed, Vietnam's economy is accepted as one of the resilient, growing economies with an average rate of approximately 7 percent for decades (Chambonnier, 2019; Norris and Zhang, 2021). By 2020, Vietnam economy national GPD's has reached USD 271.9 billion, in turn, approximately USD 2,794 per capita (Chambonnier, 2019). Significantly, Vietnam is recognized as one of the countries that accumulate economic expansion growth in 2020 by $2 \%$ regardless of the significant impact of global pandemic COVID-19 (GSO, 2020; Lee, 2021). Due to the signed FTA between EU-Vietnam, the expansion of Vietnam exports accounts for USD157.63 billion (an increase of 28.4\%), which is recognized in many products categories, including garments, shoes, and other goods to the EU, while the export to America is continually growing to USD 44.9 billion (Lee, 2021; Samuel, 2021). In line with this growing trend, Vietnam is accelerating its reformation that offers prosperous investment opportunities, more incentive policies, business opportunities, and digitalization (PwC, 2018). Additionally, Vietnam is ranked 4th for ease of doing business compared to its counter-partners in ASEAN and 70th in the global market (BriCharm Vietnam, 2020). As such, Vietnam's economy is appealing to FDI, and USD 9.24 billion are estimated to be disbursed as well as USD 15.2 billion is recorded for registered and paid-in-capital from foreign sectors (Samuel, 2021). Despite Vietnam's rapid growth and industrialization, Vietnam has been recognized to have the lowest investment for modern physical infrastructure for the next phase of development (Worldbank, 2021). In following, Vietnam is required further investment into market governance and institution, human capital, and infrastructure for the global economic integration (Chambonnier, 2019). Moreover, Vietnam's economy necessitates further support for consistent 
development and post-pandemic recovery from pandemic impacts (Norris \& Zhang, 2021). From the employment perspective, the majority is accounted for the working-age group with $52 \%$ of the population, in which $22 \%$ workforce is well-trained and own degrees or diploma certificates $(\mathrm{PwC}$, 2018). According to Dezan Shira \& Associates (2021), the labor force is mainly employed in the manufacturing, services, and agricultural sectors. To adapt to the 4.0 Industry Revolution, the Vietnam government has variously amended decrees, decisions, and resolutions to create digital transformation agenda; in fact, the impact of COVID-19 has influenced the process, especially SME sectors (Vietnamnews, 2021; PwC, 2021). For e-commerce, Vietnam has a total of USD 2.96 billion for total value goods purchasing online and USD 54 at average revenue for online shop owners (BritCham Vietnam, 2020). Thus, the impacts of COVID-19 change the behavior of consumers shifting to the online base, which accelerates the digitalization process of Vietnam (Deloitte, 2021). Therefore, Vietnam's economy has accepted to contain potential the further development with optimistic perspectives, many developments are still required to enhance the economy.

\section{Methodology}

The paper uses primary and secondary data. The first phrase to reach the objective of the paper is related to the qualitative methods by using tools of desk research of data in relativeness. After that, three in-depth interviews with 6 experts have been done to explore their opinions about the current economic position of Vietnam in the ASEAN region and all related issues. The second phase is to measure the effect of factors on the position of Vietnam in the ASEAN region, represented by the ratio between GDP of Vietnam and ASEAN by the quantitative method by using the Cobb-Doughlas function with a logarithmic form as following:

$$
\operatorname{Ln} Y_{i}=\operatorname{Ln}\left(G D P_{v n} / G D P_{\text {asean }}\right)=\beta_{1}+\beta_{2} \operatorname{LnK}+\beta_{3} \operatorname{LnL}+\beta_{4} \operatorname{LnX} / M+e_{i}(\text { Equation } 1)
$$

Where:

Y: economic contribution of Vietnam to ASEAN's GDP (calculated by the ratio between Vietnamese GDP and ASEAN's GDP)

$\mathrm{K}$ : Vietnam investment capital (million Vietnam dong)

L: Vietnam labor (million people)

$\mathrm{X} / \mathrm{M}$ : the ratio between the value of Vietnam export and import

It is also noted that the data for regression has been collected from Vietnam General Statistics Office in the period from 1995 to 2020 and regressed with support by an SPSS software package.

\section{Findings and discussions}

\subsection{Vietnam economic position in ASEAN Economic Community}

Not only in Vietnam but also in all countries in Southeast Asian countries, participation in the Association of Southeast Asian Nations (ASEAN) is considered an outstanding benchmark of the global integration process of Vietnam. After 26 years of participation, Vietnam has made great contributions in terms of peaceful cooperation and mutual development. As a result, the risks of conflicts and common problems in the region have the mechanism of exchange, discussion, and unification peacefully and predictably. Throughout many ASEAN Submits, ASEAN's economic position and political voice are seen as a regional organization on the international relationships has been recognized. Through various dialogue mechanisms, the present ASEAN becomes a crucial and comprehensive partner of powerful countries and economic centers such as the US, EU, Japan, China, and Russia. The following table expresses figures of GDP in USD at the current exchange rate over the past 20 years between Vietnam and other countries in the ASEAN region. 
Table of GDP at the current exchange rate and position of Vietnam in ASEAN

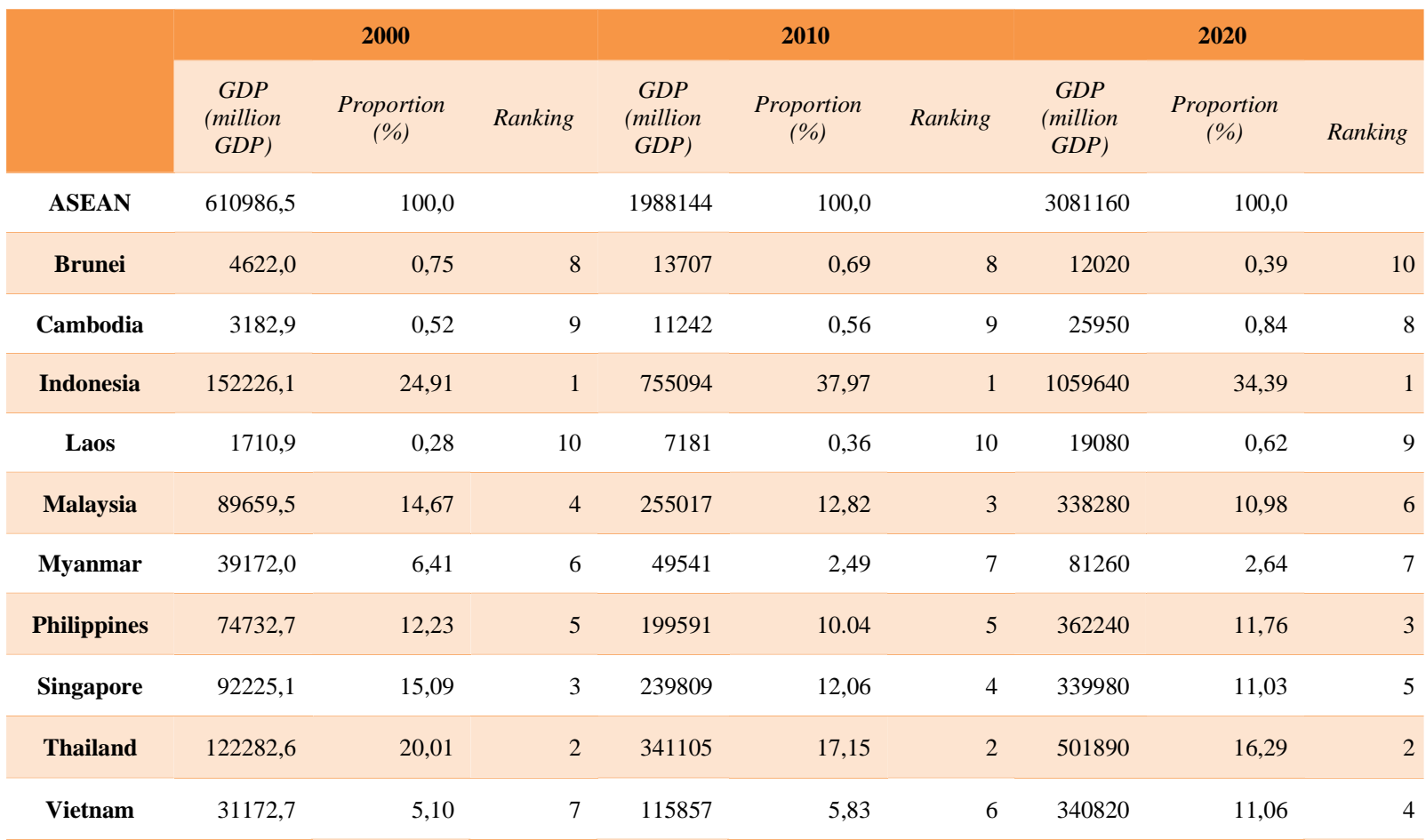

Source: Vietnam GSO (2021)

The above table shows that Vietnam's GDP was still low, ranking $7^{\text {th }}$ in 2000 , and ranking the $6^{\text {th }}$ in 2010. However, in 2020, Vietnam's economic position has been raised to the $4^{\text {th }}$ while the population ranks as the $3^{\text {rd }}$ in the ASEAN economic community. From 2001 to 2010, Vietnam reaches a relatively high growth rate compared to other countries in the region. The average annual GDP growth rate in USD achieves $12.54 \%$ per year, makes Vietnam be the $3^{\text {rd }}$ growing country in ASEAN. From 2011 to 2020, Vietnam still maintains a relatively high economic growth rate compared to other ASEAN countries, therefore, the size of Vietnam's GDP inaccurate value has continuously increased. This is the premise and condition for Vietnam to shorten the economic distance with ASEAN-6 countries and its economic scale reaches the $4^{\text {th }}$ position in 2020. However, the per capita GDP in USD of Vietnam relative to other countries in the ASEAN region also raise Vietnam's position from the $8^{\text {th }}$ to the $6^{\text {th }}$ over the last two decades. 
Table of GDP per capita and Vietnam's position in ASEAN

\begin{tabular}{|c|c|c|c|c|c|c|c|c|c|}
\hline & & 2000 & & & 2010 & & & 2020 & \\
\hline & $\begin{array}{l}\text { GDP Per } \\
\text { capita } \\
\text { (USD) }\end{array}$ & $\begin{array}{c}\text { Overall } \\
\text { average } \\
\text { rate } \\
\text { (times) }\end{array}$ & Ranking & $\begin{array}{c}G D P \\
\text { Per capita } \\
\text { (USD) }\end{array}$ & $\begin{array}{c}\text { Overall } \\
\text { average } \\
\text { rate } \\
\text { (times) }\end{array}$ & Ranking & $\begin{array}{c}G D P \\
\text { Per capita } \\
\text { (USD) }\end{array}$ & $\begin{array}{c}\text { Overall } \\
\text { average } \\
\text { rate } \\
\text { (times) }\end{array}$ & Rankin \\
\hline ASEAN & 1175,9 & 1,00 & & 3549,6 & 1,00 & & 4659.5 & 1,00 & \\
\hline Brunei & 12751,4 & 10,8 & 2 & 35270 & 9,93 & 2 & 26089.28 & 5.60 & \\
\hline Cambodia & 264,8 & 0,22 & 10 & 786 & 0,22 & 10 & 1655.39 & 0.36 & \\
\hline Indonesia & 723,4 & 0,61 & 7 & 3122 & 0,88 & 5 & 3991.62 & 0.86 & \\
\hline Laos & 324,1 & 0,27 & 9 & 1141 & 0,32 & 8 & 2625.53 & 0.56 & \\
\hline Malaysia & 3853,0 & 3,27 & 3 & 9041 & 2,55 & 3 & 10269.86 & 2.20 & \\
\hline Myanmar & 2385,2 & 2,02 & 4 & 979 & 0,27 & 9 & 1527.44 & 0.33 & \\
\hline Philippines & 988,8 & 0,84 & 6 & 2124 & 0,59 & 6 & 3330.36 & 0.71 & \\
\hline Singapore & 22959,7 & 19,52 & 1 & 47237 & 13,30 & 1 & 58902.82 & 12.64 & \\
\hline Thailand & 2013,6 & 1,71 & 5 & 5076 & 1,43 & 4 & 7190.37 & 1.54 & \\
\hline Vietnam & 401,0 & 0,34 & 8 & 1331 & 0,37 & 7 & 3498.98 & 0.75 & \\
\hline
\end{tabular}

\section{Source: Vietnam GSO (2021)}

As the table is shown, the total GDP of ASEAN countries noted at 610,986 million USD in 2000, the population was 520 million people, the GDP per capita in ASEAN countries reached 1175 USD. In 2010, the total GDP of ASEAN countries was 1,988,144 million USD, the population was 560 million people, the average GDP gained 3,550 USD. The total GDP of ASEAN reached 2,973,264 million USD in 2018, the population was 655 million people, GDP per capita gained 4539 USD. From the above table, Vietnam's GDP per capita was still low. Vietnam still faces the risk of leaving behind other countries in the region. It is also noted that Vietnam's GDP per capita was even lower than that of Laos in 1995. Vietnam equaled $48.5 \%$ of the Philippines, 39.7\% of Indonesia, $25.3 \%$ of Thailand, $14 \%$ of Malaysia, $2.7 \%$ of Singapore; Those were quite distant. In 2008, Vietnam's GDP per capita reached 1,145 USD; Vietnam, from a poor country, became a low-middle-income country. GDP in USD by PPP per capita in 2010 reached 4,388 USD, which was categorized the 6th among ASEAN countries. By PPP exchange rate, the difference between Vietnam and other countries was lower in terms of exchange rates, but the gap was still outlying, in particular, equal to $81.4 \%$ of Philippines, $72.4 \%$ of Indonesia, $36.5 \%$ of Thailand, $21.6 \%$ of Malaysia, $6.5 \%$ of Brunei, $5.6 \%$ of Singapore. In 2018, GDP per capita by purchasing power parity reached $\$ 7,460$, classifying $6^{\text {th }}$ among ASEAN countries. The growth rate of GDP per capita of Vietnam in the 2001-2010 period was $11.3 \%$ per year on average make the country the $3^{\text {rd }}$ rapid growing country in the region. In recent years, the growth rate of GDP per capita, under USD in purchasing power parity (PPP) of Vietnam, reached 8.5\%/year in the period 2011 - 2018, standing $2^{\text {nd }}$ position in ASEAN. The growth rate was classified high in the region, creating a premise to improve Vietnam's economic position in ASEAN. 
Vietnam had a high economic growth rate in comparison with ASEAN countries. From 1995 to 2005, the GDP growth rate of Vietnam was always at first in Southeast Asian countries. From 2010 to 2016, Vietnam's economic growth rate decreased compared to ASEAN countries, ranked the $7^{\text {th }}$ in 10 ASEAN countries in 2010. In 2017, 2018, Vietnam experienced a high growth rate, classified the $2^{\text {nd }}$ among 10 ASEAN countries. Vietnam's GDP growth rate in each period had changed and fluctuated. However, Vietnam's economy had reached and maintained a high economic growth rate. Also, the relatively high economic growth rate was a prerequisite for Vietnam to prevent the risk of falling further behind in terms of economic aspects.

Table 3.3: GDP growth rate and position of Vietnam in ASEAN

\begin{tabular}{|ccccccc|}
\hline & \multicolumn{2}{c}{$\mathbf{2 0 0 0}$} & \multicolumn{2}{c}{$\mathbf{2 0 1 0}$} & \multicolumn{2}{c|}{$\mathbf{2 0 2 0}$} \\
& $\begin{array}{c}\text { Growth rate } \\
(\%)\end{array}$ & Ranking & $\begin{array}{c}\text { Growth rate } \\
(\%)\end{array}$ & Ranking & $\begin{array}{c}\text { Growth rate } \\
(\%)\end{array}$ & Ranking \\
\hline Brunei & 3,0 & 10 & 2,6 & 10 & 1.2 & 3 \\
\hline Cambodia & 5,4 & 6 & 6,0 & 9 & -3.51 & 6 \\
\hline Indonesia & 4,8 & 7 & 6,2 & 8 & -2.07 & 5 \\
\hline Laos & 5,7 & 5 & 8,5 & 3 & -0.44 & 4 \\
\hline Malaysia & 8,3 & 2 & 7,4 & 6 & -5.59 & 8 \\
\hline Myanmar & 6,2 & 4 & 9,6 & 2 & 3.19 & 1 \\
\hline Philippines & 4,0 & 9 & 7,6 & 4 & -9.51 & 10 \\
\hline Singapore & 9,9 & 1 & 14,5 & 1 & -5.39 & 7 \\
\hline Thailand & 4,4 & 8 & 7,5 & 5 & -6.09 & 9 \\
\hline Vietnam & 6,8 & 3 & 6,4 & 7 & 2.91 & 2 \\
\hline
\end{tabular}

Source: Vietnam GSO (2021)

\subsection{Role of trade and capital to Vietnam's economic position in ASEAN}

In terms of trade, from under USD 1 billion of total export turnover to ASEAN countries in 1995, the export value of Vietnam to countries in the region had reached USD 10.364 billion in 2010, then increased to USD 18,253 billion in 2015 and USD 37.4 billion in 2018. The major import markets of Vietnam in Southeast Asia include Singapore, Malaysia, the Philippines, Indonesia, and Cambodia. Vietnam's major commodities exported to these countries were crude oil, rice, electronics, components, textiles, seafood, peanuts, coffee, and rubber, etc. However, Vietnam had been involved in a negative balance of trade with other ASEAN countries (Nguyen et al., 2008) with trade deficits of USD 1.8 billion in 2000, USD 6.1 billion in 2010, USD 4.6 billion in 2015, and USD 5.5 billion in 2019. Regarding the foreign direct investment (FDI) from ASEAN countries, FDI capital inflows from ASEAN had accounted for about $20 \%$ of FDI capital inflows into Vietnam over the past few years. From 1995 to 2019, Vietnam hosted 2,791 investment projects with total registered capital of 58.9 billion USD. Some ASEAN members are big investors in Vietnam such as Singapore (over 35.1 billion USD), Malaysia (13.4 billion USD), and Thailand (7.7 billion USD). After 20 years from 2000 to 2020, the positive result is shown through a regression model which has been constructed to explore the role 
of trade and capital in the improvement of Vietnam's economic position. An ordinary least square estimation is express as following:

$$
\operatorname{Ln}(\text { GDPvn/GDPasean })=0.66^{*}+0.03^{* * *} \operatorname{LnK}-0.15^{* * *} \operatorname{LnL}+0.60 * * * \operatorname{LnX} / \mathrm{M}+\mathrm{e}
$$

The estimated equation has $\mathrm{R} 2=0.873$ and confirms that the equation dependent variables is to explain to $87 \%$ of the dependent variable. Regression coefficients estimated from the above equation show that almost all of the coefficients have high significance with $99 \%$ but the model constant is with $90 \%$. In economic terms, capital and trade affect positively to Vietnamese economic position with coefficients of 0.028 and 0.603 , respectively. When the investment capital of Vietnam increases by $10 \%$, it is estimated that the ratio of Vietnamese GDP over the ASEAN would increase by $0.3 \%$. The regression affirms the important role of exports on Vietnam's economy when a $10 \%$ increase in the ratio of exports over imports would raise the ratio of Vietnamese GDP over the whole ASEANs by $6 \%$. Whilst the regression estimated the negative effect of population on the nation's economic position when an increase of $10 \%$ in population was estimated to lower the ratio of Vietnamese GDP over the ASEAN by $1.5 \%$.

\subsection{Discussions and recommendations:}

The ASEAN Economic Community represented a new step in the integration process of ASEAN countries. In the formation process, the AEC has reached a consensus and high determination of the ASEAN national leaders. And Vietnam, with the choice of deeper integration with ASEAN through the AEC process, needs to come from the point of view of strategic priorities throughout its own international and regional economic integration. Also, the AEC is the first step towards the process of institutionalizing ASEAN into a unified economic entity, which is a unified market and production base, becoming a legal entity representing the members in the international forums and other global organizations. The implementation progress of the AEC allows Vietnam to approach a broader and more stable development space, minimizing the disadvantages due to the position of a "third country" concerning bilateral commitments that other ASEAN countries obtain from major non-ASEAN economic partners. Not actively engaging in the AEC means self-isolating and limiting our development opportunities. Besides, Vietnam has been a fast-growing and dynamic economy and has built a new position and force in the international market in general, and in the ASEAN in particular, allowing to engage in forming the ASEAN development roadmap. The new position and force also increase the expectations of member and partner countries of ASEAN in Vietnam's contributions to the ASEAN Community and ASEAN's foreign affair relations. The general analysis in the above approach to the AEC progress shows that priority for the AEC roadmap of Vietnam not only comes purely from economic motives but also contains geostrategic considerations, which create effects for a series of other regional and bilateral integration frameworks of Vietnam in the coming time. To enhance the economic position of Vietnam in the AEC implementation process, it is necessary to effectively implement the following key solutions:

- Maintaining a high growth rate in the next 10-15 years is a crucial mission to reach the sustainable development goal. The growth rate of $6.5 \%$ - $7 \%$ per year will ensure that Vietnam achieves the target of per capita income meeting the requirements of a high-middle-income country, which is estimated at USD 8,000-9,000, escaping from the middle-income trap. Also, combining growth with increased efficiency in achieving growth targets. Focus on improving investment efficiency, ICOR needs to be reduced below 5, enhances labor productivity, twice as much as now, more than USD 4,000 per worker, targets to long-term growth points of the economy. Combining growth with restructuring the economic sector towards sustainability. In the future, promotion towards the development of industries and services should be done to reduce the proportion of agriculture. The proportion of the agricultural sector will be less than $10 \%$ by 2030 and ensure growth associated with the major macro balances of the economy; Besides, it is to confirm budget deficit is below $4 \%$ of GDP, no excess of 
$50 \%$ of foreign debt to GDP. More of that, in the next 10 to 15 years, the HDI, poverty reduction coefficients, and job problems are hoped to change positively in which the economic growth is associated with equal conditions and development opportunities for all citizens. The GINI coefficient and the indicator of social equity over a 10 to15 year period will be from 0.4 to 0.3 , which is at top of the high equity.

- Today, improving labor productivity is an urgent need for the economic growth of Vietnam. GDP growth of Vietnam since 2005 has been obtained by elements that offset the weakness and decline in productivity growth, but these factors have now reached their natural limits. Therefore, it is necessary to restart increasing labor productivity to increase Total Factor Productivity (TFP), which contributes mainly to the GDP growth of Vietnam. Reforms that have a direct impact on productivity growth enable stronger and more effective participation of the private sector, creating the premise for stimulating strong growth in the coming decades. At the same time, continue to actively support the ongoing economic restructuring process and global integration progress through modernizing and commercializing agriculture, improving the position of Vietnam in the global value chain, and building a solid and reliable market economy institution.

- The role of human resources is increasingly important in the conditions of globalization and international integration. Developing human resources, especially quality human resources which are closely attached to the development of science and technology is a decisive factor to restructure the economy, transform the growth model, be the most important competitive advantage, and ensure fast, efficient and sustainable development. Therefore, that the economy focuses only on capital, exploiting raw resources and cheap labor for development as we have done in recent years has shown many weaknesses and inadequacies. In addition, it has begun to show that it is unachievable for development without innovation in the direction of development, including the use of human resources and knowledge resources to develop the country. Human resource development is an urgent requirement for industrialization and modernization in our country. Simultaneously, it is also a long-term mission to gradually turn our economy into a knowledge economy. Hence, it is necessary to stimulate the training of quality workers, paying special attention to creating a force of strong enough experts to meet the development requirements of the economy in the current period. This is considered an opportunity, but also a challenge for Vietnam. In the context of international integration, the country can take advantage of the experience in education and training of other countries, but we also face many difficulties because the Vietnamese education and training system are somehow still underdeveloped. From 10 to 15 years, creating quality human resources is not easy. To have a force of good leaders, managers, experts, good corporate governance, skilled workers, and top scientific and technological staff, it is necessary to pay attention and special care to the drastic and powerful solutions on education and training. It is essential to train human resources to meet the diverse and multi-faceted requirements of technology and development levels of different fields. Therefore, it seems essential to focus on improving the quality of training, attaching training with the practical needs of users and the needs of the economy; renewing fundamentally and comprehensively the national education system in line with international standards; building a system of modern and diverse human resource training institutions, besides forming and developing a learning society; making policies to train and develop a team of leading experts, good entrepreneurs and skilled workers; training, building and developing key human resource groups in key industries such as information technology, mechanics - automation, new materials, marine technology, biotechnology, medicine, energy quality, environmental technology and space technology. Implementing programs and projects to train quality human resources for key and spearhead industries and fields. Special attention is paid to developing and fostering talents and training human resources for the development of the knowledge economy. Renovate fundamentally and comprehensively Vietnam education in the direction of standardization, modernization, socialization, democratization, and international integration. In particular, strongly renovating the educational management 
mechanism, developing a team of teachers and administrators are the key stages. Improving physical strength and enhancing the stature of Vietnamese people. The fundamental goal is to sustainably improve the stature of the Vietnamese people. Renovating the policy of using human resources to stimulate motivation and unleash human creativity. Developing the labor market, building appropriate mechanisms and tools to effectively use human resources, creating motivation for the development of human resources themselves.

Developing quality human resources must be closely attached to the development of science and technology. That is for the quality human resources and modern science-technology form a new production force with power and quality of a new level. In the coming time, it is required to renew fundamentally and synchronize the organizational structure, management mechanism, and scientific and technological operation mechanism, direct science and technology into industries serving industrialization, modernization, transforming growth models, increase rapidly productivity, quality and efficiency. The development of human resources, especially quality human resources, is not a new problem for Vietnam. For a long time, promoting the human factor has been taken into account, there have been many policies and solutions to promote the human factor in constructing and developing country. At the enterprise, sector, and local levels, there have been many policies and solutions on training, attracting, and using quality human resources. However, it seems that solutions for both at the sector-local and national level have not been sufficient and effective enough so far. Quality human resources have been seriously in shortage; National major industries need high-quality human resources but some estimation warning that only about $40 \%$ of that can meet the demands. Meanwhile, the potential of Vietnamese people is assessed as not low; It can be affirmed that Vietnamese people completely meet the requirements of providing sufficient quality human resources to serve the development of economic sectors of the country. This is considered an important factor in attracting domestic and foreign investment in high-tech industries in Vietnam.

\section{Conclusion}

The integration of Vietnam's economy into the ASEAN Economic Community (AEC) is an inevitable development after the achieved results of ASEAN's cooperation and economic connection. The AEC is an open regional economic integration model. The implementation of the AEC will bring in multi-dimensional impacts on member countries, and the extent of these impacts will depend on the level of regional and international economic integration, competitiveness, and effectiveness of policy reform in each country. To date, Vietnam has made many major contributions to turn ASEAN into a framework of peaceful cooperation and mutual development. Beginning with ASEAN-6 to ASEAN-7, then ASEAN-10, it is noticeable that the economic position and political voice of Vietnam, a responsible member in the region, has been recognized. Through various dialogue mechanisms, Vietnam now has become a major member of the ASEAN Economic Community. In terms of each specific priority sector, Vietnam is still in a lower position but approaching ASEAN-6 members as a key member of the institution. This situation requires Vietnam to have both short-term and long-term solutions, which rapidly increase internal resources and improve national competitive capacity in every industrial and priority sector. The integration of Vietnam in the AEC will also create multi-dimensional positive impacts. The process of implementing the AEC of Vietnam has advantages, but it also encounters difficulties that need to be overcome to absorb the effect positive impacts of the integration process and minimize the negative impacts of this process. 


\section{References}

[1]. BritCham Vietnam (2020). E-commerce Reports. Available at https://britchamvn.com/wpcontent/uploads/2020/12/Vietnam-2020-E-Commerce-Report.pdf

[2]. Chambonnier, M. A. (2019). Macro Poverty Oultook-Vietnam. The World Bank. Available at https://pubdocs.worldbank.org/en/972091563917611616/mpo-vnm.

[3]. Deloitte (2021). The Vietnam Consumer Survey Staying resilient amidst Headwinds. Available at https://www2.deloitte.com/content/dam/Deloitte/sg/Documents/consumer-business/sea-cbvietnam-consumer-2021.pdf.

[4]. General Statistics Office of Vietnam (2016). Movements and socio-economic situation of Vietnam in 5 years 2011-2016. Statistical Publishing House.

[5]. General Statistics Office of Vietnam. Statistical Yearbook 2002, 2005, 2012, 2018, 2020. Statistical Publishing House

[6]. Ha, V. H. (2013). Joining the ASEAN Economic Community and its implications for Vietnam international trade. Journal of science: Vietnam National university, Economics and Business, 29(4), 44-53.

[7]. Ministry of Industry and Trade of Vietnam (2002). Survey Vietnam's deeper integration into the Asean".

[8]. Nguyen, D. D. (2018). ASEAN: From Association to Community - Outstanding issues and impacts on Vietnam, Vietnam academy of social sciences, Ha Noi.

[9]. Nguyen, H. G., Nguyen, H. C. \& Nguyen, T. Q. (2008). Current ASEAN cooperation and participation and the participation of Vietnam. Political Theory Publishing House, Hanoi.

[10]. Nguyen, H. S., Nguyen, A. T., Vu, T. H. \& Nguyen, T. M. P. (2015). Vietnam's integration into AEC: Opportunities and challenges for development. Journal of Economics and Development, Vietnam National university, 212(2), 13-24.

[11]. Nguyen, M. T. (2020). Position, hindering factors and solutions to improve Vietnam's national competitiveness. Journal of Duy Tan university, 20, 217-239

[12]. Pham, M. C. \& Vuong, Q. H. (2009). Vietnam economics: Economic fluctuation and development. National Political Publishing House..

[13]. Phan, H. D. (2007). International Business Economics of Vietnam. Hanoi National University Publishing House.

[14]. Tran, D. T. \& Chu, M. H (2015). Assessment achievement after 30 years innovation and identification position of Vietnam economy. Journal of Vietnam Institute of Economics, 11, 255-279 